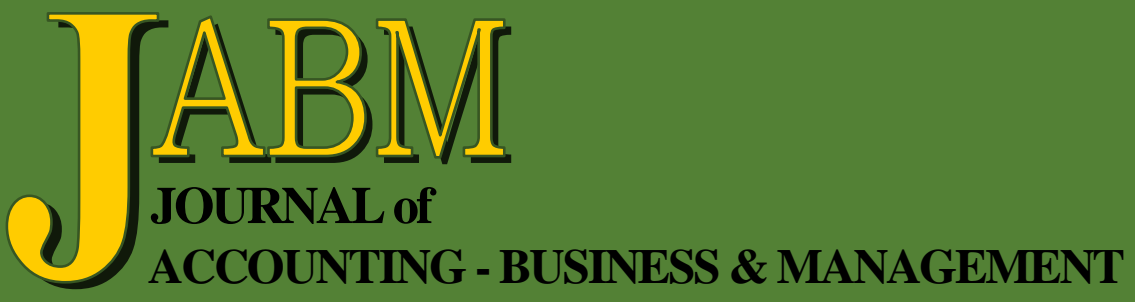

The Relationship between the Ownership Structure, Capital Structure and Performance

Ali Al-Thuneibat

The Effect of Self Efficacy and Information Quality on Behavioral Intention with Perceived Usefulness as Intervening Variable

Muslichah

Empirical Analysis of Factors Influencing Use of Internet on Ships

A. S. Saravanan, Jayalakshmy Ramachandran, A. Seetharaman, Karripur Nandakumar, and Capt. Kailash C. Joshi

Pawnshops Regulatory Environment: A Readability Analysis

Geralyn Miller, Steven A. Hanke, and Hui Di

Auditor Litigation and the Penalties on U.S. Client Firms after the Private Securities Litigation Reform Act

Nana Y. Amoah, Anthony Anderson, Isaac Bonaparte and Kyle Meyer 
Journal of Accounting - Business \& Management vol. 25 no. 1 (2018) 21-34

\title{
The Effect of Self Efficacy and Information Quality on Behavioral Intention with Perceived Usefulness as Intervening Variable
}

\author{
Muslichah*
}

\begin{abstract}
The rapid development of technology requires universities to develop an integrated academic information system to support the education process. With the application of the information system, universities can provide better information services to students. The aim of this study is to examine the influence of self-efficacy and information quality on behavioral intention toward academic information system with perceived usefulness as an intervening variable. This study used survey questionnaire in collecting data from one higher institution - STIE Malangkuçeçwara (Malangkuçeçwara School of Economic). The population in this study is all students in the sixth semester. A questionnaire was administered to all 377 students, 311 were returned yielding a response rate $82.5 \%$. This study has three significant findings. First, the direct effect of self-efficacy on behavioral intention to use academic information system (AIS) is significant. Second, the direct effect of information quality on behavioral intention to use AIS is significant. Third, The indirect effect of self-efficacy and information quality on behavioral intention to use AIS through perceived usefulness is not significant.
\end{abstract}

Keywords: self efficacy, information quality, academic information, perceived usefulness.

\section{INTRODUCTION}

The use of technology has become an essential topic in information systems research and studied by researchers from various disciplines. Implementation of information systems at universities has increased the interest of researchers to study the phenomenon. Expanding the introduction of new technologies into the learning environment has prompted researchers to identify factors affecting user acceptance of the system (Yi \& Hwang, 2003). Technology acceptance has become an essential part of a research. The term first proposed by Davis (1989) which describes the user behavior towards the application of technology in the organization (Malhotra \& Galetta, 1999).

The information system has the potential to improve the performance of the white collar substantially (Edelman, 1981; Curley, 1984; and Sharda et al., 1988). However, performance achievement can be hampered because users refuse to accept and use the system already available (Bowen, 1986; Young, 1984). User acceptance has been a long-studied issue in management information systems research (Swanson, 1974; Lucas, 1975; and Swanson, 1987).

Many researchers have focused their research on factors that influence the acceptance of information systems and utilization among users (e.g., Davis, 1989; Davis et al., 1989; Mathieson, 1991; and Moore \& Benbasat, 1991). Davis (1989)

\footnotetext{
* STIE Malangkuçeçwara d/h ABM (Malangkuçeçwara School of Economic), Malang, East Java, Indonesia. Email: muslichahmachali@yahoo.com.
} 
proposed a model of technology acceptance. The model is adapted from the theory of reasoning (TRA) developed by Ajzen and Fishbein (1980) and Fishbein and Ajzen (1975). Both models are most widely accepted and used by researchers who examine information systems. The technology acceptance model (TAM) states that perceived usefulness and perceived ease of use are the variables that can influence the individual's attitude toward the use of information systems (Davis et al., 1989).

Perceived usefulness is the level of which a person believes that using a particular system can improve his performance. People will use a computerized information system if they think that the system will help them do the job better. Previous research was conducted by Roca and Gagne (2008), and Butt (2016) found that perceived usefulness in information systems can improve the user's intent to use the system. However, Jaturavith (2007) and Juniwati (2014) found the opposite that there was no effect of perceived usefulness on behavioral intention

Besides perceived usefulness, other variables that influence users to use information systems are self-efficacy and information quality. Self-efficacy is an assessment of a person's ability to use information systems. Self-efficacy is an essential variable for understanding user responses to information systems. Users who can operate the system will have the ability to search and find information quickly. Khairi and Baridwan (2015) found that self-efficacy has a positive effect on behavioral intention.

Previous research has investigated the importance of information quality in information systems (Omar et al., 2010; Sari et al., 2017). Quality of information can result in better decision making. Information must have value for the recipient to make effective decisions (Raghunathan, 1999; Rabren, 2010). Prior research shows that information quality has a positive effect on perceived usefulness (Ahn et al., 2007; Wang \& Lin, 2012).

Two essential reasons motivate the current study. Firstly, prior research has produced inconclusive results concerning the effect of perceived usefulness on behavioral intention. Secondly, there is only few research that studies the impact of information quality and self-efficacy in predicting customer behavior toward information system. This study will enrich research related to technology acceptance model by including self-efficacy and information quality as one of a determinant of behavioral intention.

\section{LITERATURE REVIEW AND HYPOTHESES DEVELOPMENT}

\subsection{TAM (Technology Acceptance Model)}

TAM proposed by Davis (1989) is one of the most widely used models in previous research. The model explains the factors that determine the acceptance of Information Technology. Technology acceptance model (TAM) is an extension to Theory of reasoned action proposed by (Fishbein \& Ajzen, 1975; Ajzen \& Fishbein, 1980). Davis (1989) defines Perceived Usefulness as the level at which a person believes that using a particular system can improve his performance. Furthermore, Davis defines perceived ease of use as the level of belief that in the use of a specific system is not required a hard effort.

TAM proposed perceived usefulness (PU) and perceived ease of use (PEOU) as the fundamental determinants of IT adoption. TAM identifies factors that affect the acceptance of information technology. TAM describes the causal relationship between the external variables of (perceived usefulness and ease of use), attitude, intention, and behavior of actual system usage (Davis et al., 1989, p. 983). In this study, 
there are four variables, and two of them are variable from TAM: perceived usefulness and behavioral intention. The original TAM (Davis et al., 1989) is depicted in Figure 1.

\section{Figure 1}

Technology Acceptance Model

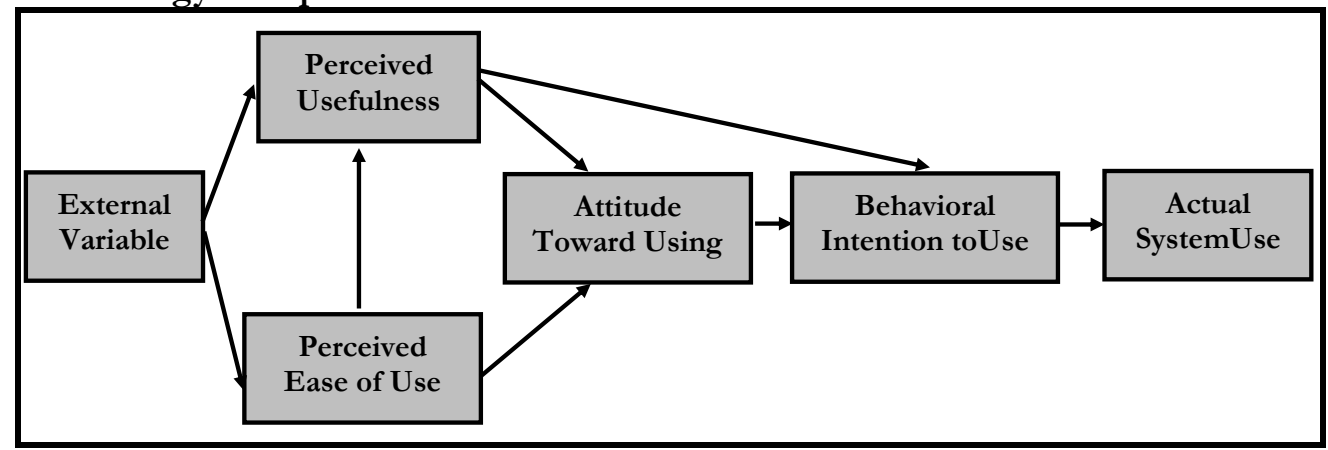

\subsection{Self-Efficacy}

Self-efficacy is defined as the individual's belief that he is capable of performing a task assigned to him. Self-efficacy is the individual's estimate of his or her own ability to play a specific task in a particular situation. The higher the employee's perceived ability to perform the task, the higher the employee's self-efficacy. Bandura (1986) states that self-efficacy is a belief in one's ability to drive motivation, cognitive sources, and the set of actions necessary to meet given situational demands. Self-efficacy also refers to a person's belief about his or her chances of accomplishing a specific task.

Ajzen (1988) research has shown that perceived behavioral control is very similar to the concept of self-efficacy, which is a decisive factor affecting behavior selection, efforts, continuance, and performance level under different scenarios (Bandura 1982, 1997). Gist and Mitchell (1992) mentioned that self-efficacy has three aspects. First, self-efficacy reflects an individuals' judgment on whether they are capable of implementing a specific task. Second, the judgment on self-efficacy changes as the individual obtains information and experiences. Third, a self-efficacy judgment involves a motivational factor which directly mobilizes the individuals' behaviors.

According to Bandura, the most important source of increasing self-efficacy enactive mastery - that is, gaining relevant experience with the task or job. The second source is vicarious modeling - becoming more confident because you see someone else doing the work. The third source is verbal persuasion: people will be more optimistic because of someone who can convince you that you already have the skills to be a successful person. Finally, Bandura argues that arousal increases self-efficacy. Arousal Passion causes people to have energy, which further encourages people to improve their performance. High self-efficacy employees believe that (1) they have the necessary skills to do the job, (2) they have the required effort, and (3) they always have high performance. There are three ways in which Self-efficacy can affect learning:

1. It affects activities and goals that an individual has chosen for themselves. In a sales contest at Pioneer Telephone Cooperative in Kingfisher, Oklahoma, employees with low self-efficacy didn't set challenging, or "stretch," goals. These people weren't lazy; they merely thought that they would fail to achieve a lofty goal. The high self-efficacy employees felt that they were capable of attaining high-performance goals-and did so.

2. It influences the effort that individuals exert on the job. Individuals with high selfefficacy work hard to learn new tasks and are confident that their efforts will be 
rewarded. Low self-efficacy individuals lack confidence in their ability to succeed and see their extra attempt as futile because they are likely to fail anyway.

3. It affects the persistence with which an individual stays with a complex task. Because high self-efficacy people are confident that they will perform well, they are likely to persist in spite of obstacles or the face of temporary setbacks. When people believe that they are not capable of doing the required work, their motivation to do a task will be low.

\subsection{Academic Information Systems}

Academic Information Systems (AIS) are computer information systems that deal with advising, course catalogs, student information, and data, including financial information. Within the Academic Information System, there is a variety of personal information about students. Furthermore, the data about grades obtained by students each semester is also recorded in the AIS. In the AIS, students are facilitated in accessing any information provided by the college.

\subsection{Information Quality}

Information quality refers to as "the degree to which the quality of the information that the portal provides and its usefulness for the user enables them to accomplish the stated goal of the system". Information quality is considered one of the most important success factor when investigating overall information system success of any given system (McKinney et al., 2002). In the context of an academic information system, it is defined as "the ability of the academic information system to provide its students with new, accurate, clear, and easy to understand information" (Urbach et al., 2010). It is also referred to as the quality of e-academic information system output and is measured by different semantic attributes (Wang \& Liao, 2008).

Monczka et al. (1998) stressed that information quality should encompass the elements of accuracy, timeliness, adequacy, and credibility of information exchanged. Similar attributes were used in the studies of Li and Lin (2006), Li et al. (2006), and Forslund and Jonsson (2007) to measure information quality. Moberg et al. (2002) measured information quality concerning timeliness, accuracy, completeness, adequacy, and credibility. However, Miller (2005) measured information quality based on accuracy, believability, objectivity, precision, and reliability of the information, relevancy, timeliness, completeness and information appropriateness, comprehensibility, interpretability, consistency, conciseness, format and appearance of the information, accessibility, security and availability.

\subsection{Perceived Usefulness}

Perceived usefulness is defined as a person's level of confidence that by using a particular technology he will improve his performance (Van der Heijden, 2003). Also, perceived usefulness is defined as the extent to which consumers feel the online website could add value and efficacy to them when performing online shopping ( $\mathrm{Hu}$ et al., 2009; Lai \& Wang, 2012). Similarly, Davis (1989), in favor of Van der Heijden (2003), defined that the perceived usefulness is the degree of a person's belief that using a particular system would enhance his performance.

\subsection{Behavioral Intention}

TRA/TPB define Intentions as the number of efforts that someone wants to do for a particular goal to be achieved (Ajzen, 1991), "behavioral plans that...enable attainment of a behavioral goal" (Ajzen, 1996), or simply "proximal goals" (Bandura, 
1997). Intention represents a person's conscious plan to exert effort to carry out a behavior (Eagly \& Chaiken, 1993, p. 168).

There are two behavioral intentions investigated in this study include reuse intentions and word-of-mouth (WoM) communication. Repurchase intentions are defined as "the individual's judgment about using again a designated system". From this definition, it is clear that reuse behavior occurs when students use the systems for the second or more time; and the reason for using again is mainly triggered by customer experience towards the current systems. Thus, it is noticed that students are more likely to use again if they think that what they have received from the systems was worth. WoM communication is defined as "informal communications directed at other students about the usage, or characteristics of particular systems". Students engage in WoM communications because they want to reduce the tension caused by positive or negative experiences, to gain support from others and share opinions with them (Wirtz \& Chew, 2002).

\section{HYPOTHESES DEVELOPMENT}

\subsection{The Effect of Self Efficacy on Attitude Toward Academic Information System}

Many previous studies have been done to investigate the impact of self-efficacy on computer-related use. Ariff et al. (2012) proved that self-efficacy influences the behavioral intention to use Accounting Information System based IT. Self-efficacy will stimulate oneself to make more efforts to achieve expected results. Moreover, Eastin (2002) and O'Cass and Fenech (2003) showed that personal internet self-efficacy has a positive effect on user acceptance of information system. Based on the studies that have been described, the researcher proposed an alternative hypothesis as follows:

$\mathbf{H}_{1}$ : self-efficacy has a direct effect on behavioral intention to use academic information system.

\subsection{The Effect of Self Efficacy on Behavioral Intention to Use Academic Information System with Perceived Usefulness Intervening Variable}

Several studies have found that information system self-efficacy is positively related to perceived usefulness and perceived ease of use (Guriting \& Ndubisi, 2006). Hsu et al. (2013) state that there is an influence of self-efficacy on perceived usefulness and the impact on perceived ease of use is not significant. Furthermore, Ma et al. (2005) investigated student teachers' perceptions of computer technology about their intention to use computers. The results indicated that student teachers' perceived usefulness of computer technology has a direct effect on their intention to use it. It also supported by other researchers such as Mathieson et al. (2001); Moon and Kim (2001); and Ramayah and Ignatius (2005) also found that perceived usefulness is significant and positively influences the behavioral intention. Thus, it is hypothesized that

$\mathbf{H}_{2}$ : self-efficacy has an indirect effect on behavioral intention to use academic information system through perceived usefulness.

\subsection{The Direct Effect of Information Quality on Behavioral Intention to Use Academic Information System}

Quality of information is the quality of output in the form information generated by the information system used. Adequate information and excellent quality of information seems wi have an impact on the users' behavioral intention. Liu et al. (2000) argue that the best quality of information will improve user perceptions and improve the behavioral intention to use information system. Thus, the higher 
the information quality, the higher the behavioral intention to use the information system.If the quality of information is useful, then the users of the system can benefit more from the system so that it can impact on behavioral intention using information systems.

$\mathbf{H}_{3}$ : information quality has a direct effect on behavioral intention to use academic information system.

\subsection{The Indirect Effect of Information Quality on Behavioral Intention Toward Academic Information System with Perceived Usefulness as Intervening Variable}

The quality of information is an essential determinant of perceived usefulness. Furthermore, Li (1997) states that if the system produces quality information and then the information is useful to the user's work then the user will promote the system to other co-workers, so there will be additional new users who try to take advantage of the system. For students use the academic information system to obtain information related to academic, finance and library. The accuracy, completeness, and currency information collected will be essential. Also, the presentation of information must also effectively address user interpretation and understanding to assist them in completing a task (Ahn et al., 2007; Lin, 2007). User perceptions of the quality of the information provided, therefore, determine whether the service or system is useful ( $\mathrm{Lin} \& \mathrm{Lu}, 2000$ ). Furthermore, Teo et al. (2008) found that perceived usefulness positively and significantly affects pre-service teacher's intent to use technology. In other words, a student teacher will tend to use technology if they think the technology is useful in helping them get the job done more effectively. Furthermore, Sari et al. (2017) found that information quality, system and service quality of e-government influences citizens perceived usefulness, which in turn influences citizens adoption/attitudes toward the use of the e-government system

$\mathbf{H}_{4}$ : information quality has an indirect effect on behavioral intention toward academic information system through perceived of usefulness.

Based on the hypotheses development above, research model of this study can be developed as follows:

Figure 2

\section{Research Model}

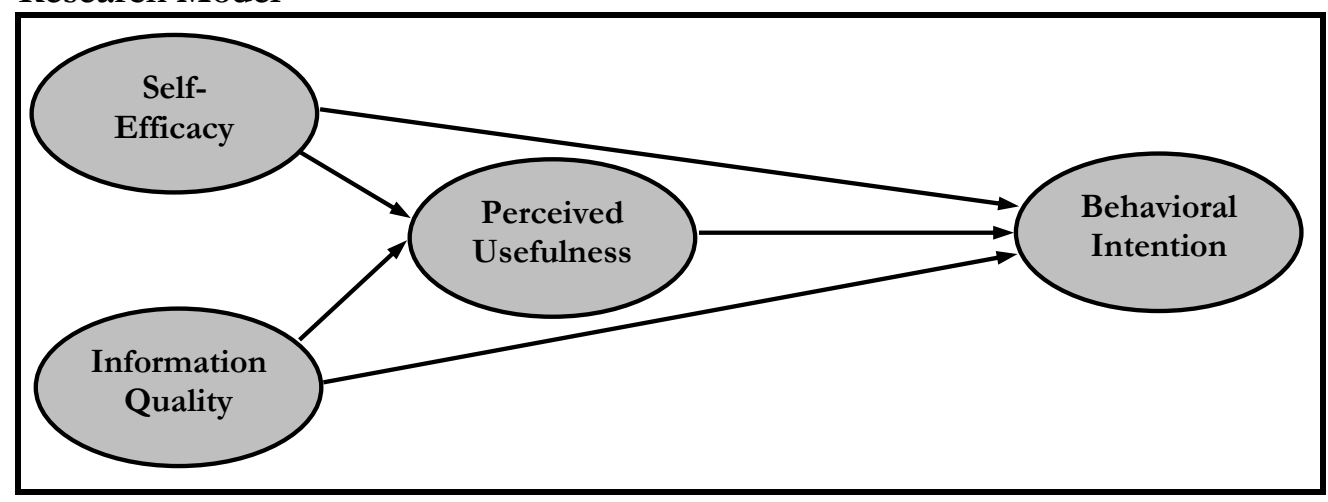

\section{RESEARCH METHOD}

\subsection{Population and Sample}

This study uses quantitative research approach. The population in this study is all students in the sixth semester (batch 2014) studying at STIE Malangkuçeçwara Malang 
(Malangkuçeçwara School of Economic). The criteria are essential to make sure that they understand the academic information system in their institutions. The data used in this study is the primary data which collected through a structured questionnaire. The questionnaire contains two parts. The first part of the survey sought demographic information from the respondents such as gender, age, program, and frequency of using academic information system. The second part is asking for respondents' perception of usefulness, self-efficacy, information quality dan behavioral intension. A total number of students batch 2014 is 377 students. A questionnaire was administered to all 377 students, 311 were returned yielding a response rate $82.5 \%$.

\subsection{Definition and Variable Measurement}

There are four variables used in this study, namely perceived usefulness, information quality, self-efficacy and behavioral intention. The variables can be described as follows:

\section{a. Self-Efficacy}

Self-efficacy is defined is defined as “an individual's perception of his or her own ability to use computer in the accomplishment of a task, rather than reflecting simple component skill" (Compeau \& Higgins, 1995). Four items were developed to measure self-efficacy. Respondents responded on a 5 point scale ranging from 1 (strongly disagree) to 5 (strongly agree). A high numerical response a perception of the high degree of self-efficacy. Cronbach alpha for this measurement is excellent, that is 0.850042

\section{b. Information Quality}

Information quality refers to as the degree to which the quality of the information that the portal provides and its usefulness for the user enables them to accomplish the stated goal of the system. Four items were developed to measure information quality. Four questions designed to measure information quality. Participants responded on a 5 point scale ranging from 1 (strongly disagree) to 5 (strongly agree).A high numerical response a perception of the high degree of information quality and a low numerical response a perception of the low degree of information quality. This measurement has a very good Cronbach alpha, which is 0.844972 .

\section{c. Perceived Usefulness}

Perceived usefulness is defined as the individual's perception that using the new technology will enhance or improve his or her performance (Davis, 1989). Participants responded on a 5 point scale ranging from 1 (strongly disagree) to 5 (strongly agree). A high numerical response a perception of the high degree of perceived usefulness. Cronbach alpha for this measurement is 0.815894 .

\section{d. Behavioral Intention}

Behavioral intention is the perceived of the individual either wants to perform the task or no. Three items were developed to measure behavioral intention. Respondents responded on a 5 point scale ranging from 1 (strongly disagree) to 5 (strongly agree). A high numerical response a perception of the high degree of behavioral intention. Cronbach alpha obtained for this measurement is 0.913609 .

\section{RESEARCH FINDINGS}

\subsection{Respondents Background}

Table 1 below shows demographics statistics of students indicating the frequency distribution of each characteristic under study together with its percent in the form of a table. 
Table 1

Demographic Data of the Respondents

\begin{tabular}{lcc}
\hline \multicolumn{1}{c}{ Variable } & Frequency & Percentage (\%) \\
\hline Age: & 78 & 25 \\
- Between 15-19 years & 233 & 75 \\
- Between 20-24 years & - & - \\
- Between 25-29 years & - & - \\
- More than 30 years & & \\
Gender: & 122 & 39.2 \\
- Male & 189 & 60.8 \\
- Female & & \\
Educational Background: & 153 & 49 \\
- Management & 158 & 51 \\
- Accounting & & \\
Usage of AIS in One Semester: & 75 & 24.1 \\
- Once & 140 & 45.0 \\
- Twice & 52 & 16.7 \\
- Three times & 27 & 8.7 \\
- Four times & 11 & 3.5 \\
- Five times & 6 & 1.9 \\
- More than five times &
\end{tabular}

Table 1 explains the gender distribution of the participants in the survey. Female participants constitute a significant portion of the sample and account for $60.8 \%$ of the participants surveyed. $39.2 \%$ of participants were males who participated in the survey. It indicates a high discrepancy ratio between male and female. Based on the distribution of program study taken by students participating in the study. The data was summarized in two groups: management and accounting. About 49\% of the participant's study management whereas $51 \%$ of the participants study accounting. Furthermore, regarding frequency of using academic information system (AIS) in one Semester. Most of the respondents, 140 (45\%) using AIS twice. Moreover, 75 respondents $(24.1 \%)$ using AIS once, 52 respondents $(16.7 \%)$ using AIS three times, 27 respondents $(8.7 \%)$ using AIS four times, 11 respondents $(3.5 \%)$ using AIS five times and $1.9 \%$ using AIS more than five times.

\subsection{Hypotheses Testing}

Table 2

Total Effects

\begin{tabular}{lcccccr}
\hline & $\begin{array}{c}\text { Original } \\
\text { Sample } \\
(\mathbf{O})\end{array}$ & $\begin{array}{c}\text { Sample } \\
\text { Mean } \\
(\mathbf{M})\end{array}$ & $\begin{array}{c}\text { Standard } \\
\text { Deviation } \\
(\text { STDEV) }\end{array}$ & $\begin{array}{c}\text { Standard } \\
\text { Error } \\
(\text { STERR) }\end{array}$ & $\begin{array}{c}\text { T-Statistics } \\
(\mid \mathbf{O} / \text { STERR } \mid)\end{array}$ & p-value \\
\hline IQ $\rightarrow$ BI & 0.3072 & 0.3072 & 0.0830 & 0.0830 & 3.7016 & 0.0003 \\
$\mathbf{I Q ~} \rightarrow$ PU & 0.2252 & 0.2395 & 0.1171 & 0.1171 & 1.9236 & 0.0553 \\
$\mathbf{P U ~} \rightarrow$ BI & 0.0934 & 0.0816 & 0.0931 & 0.0931 & 1.0033 & 0.3165 \\
$\mathbf{S E ~} \rightarrow$ BI & 0.5146 & 0.5216 & 0.0805 & 0.0805 & 6.3901 & 0.0000 \\
$\mathbf{S E ~} \rightarrow$ PU & 0.3358 & 0.3400 & 0.1208 & 0.1208 & 2.7795 & 0.0058 \\
\hline \multicolumn{7}{c}{ T-table $=\mathbf{1 . 9 6 7}$} \\
\hline
\end{tabular}

\section{a. Hypothesis 1}

Hypothesis 1 states that self-efficacy has a direct effect on behavioral intention to use academic information system. From the Table 2, it can be seen that t-statistics self-efficacy towards behavioral intention to use academic information system is 6.3901 $(p=0.0000<0.05)$ which is higher than the value of t-table 1.967. It indicates that the 
effect of self-efficacy on behavioral intention to use academic information system is positive and significant. Based on the result, it can be said that hypothesis 1 is supported.

\section{b. Hypothesis 2}

Hypothesis 2 states that self-efficacy has indirect on behavioral intention to use academic information system through perceived usefulness. Table 2 shows that the $t-$ value of the effect of self-efficacy on perceived usefulness is 2.7795 which is greater than the value of t-table 1.967. This finding indicates that the effect of self-efficacy on perceived usefulness is significant. Furthermore, Table 2 shows that the effect of perceived usefulness on behavioral intention is not significant $(\mathrm{t}$-statistics $=1.0033<\mathrm{t}-$ table $=1.967$ and $\mathrm{p}$-value $=0.3165>0.005)$. Because one of the to paths is not significant. it can be concluded that the indirect effect of self-efficacy on behavioral intention to use academic information system through perceived usefulness is not significant. Thus hypothesis 2 is rejected.

\section{c. Hypothesis 3}

The third hypothesis of the model requires a test of the expected positive and significant effect of information quality behavioral intention. Table 2 shows that information quality positive and significant impact on behavioral intention to use academic information system. Furthermore, Table 2 also shows that the t-value of the effect of information quality on behavioral intentions 3.7016 which is greater than the value of t-table 1.967 (p $0.0003<0.05$ ). Hence. the resulting support for hypothesis 3 .

\section{d. Hypothesis 4}

It is expected in hypothesis 4 that Information quality has an indirect effect on attitude toward academic information system through perceived of usefulness. The result demonstrates the significant effect of Information quality on the behavioral intention with t-statistics $>$ t-table $(1.9236>1.967)$. Moreover. Table 2 also shows that the effect of perceived usefulness on behavioral intention is not significant (t-statistics= $1.0033<\mathrm{t}$-table $=1.967$ and $\mathrm{p}$-value $=0.3165>0.005)$. Because one path is not significant, it can be concluded that the indirect effect of information quality on behavioral intention to use academic information system through perceived usefulness is not significant. Thus hypothesis 4 is rejected.

Based on the explanation above, hypotheses testing can be summarised in Table 3 as follows:

\section{Table 3}

Summary of the Results

\begin{tabular}{ccc}
\hline \multirow{2}{*}{ Path } & & \multicolumn{2}{c}{ Results } \\
\cline { 2 - 3 } & Direct & Indirect Effect \\
& Effect & (Through Perceived Usefulness) \\
\hline SE $\rightarrow$ BI & Supported & Not Supported \\
& (Hypothesis 1) & (Hypothesis 2) \\
IQ $\rightarrow$ BI & Supported & Not Supported \\
& (Hypothesis 3) & (Hypothesis 4) \\
&
\end{tabular}

\section{CONCLUSIONS, DISCUSSION AND DIRECTION FOR FUTURE RESEARCH}

The purpose of this research is to study the effect of self-efficacy and information quality on behavioral intention toward academic information system with perceived usefulness as an intervening variable. There are three critical findings of this study. First, the direct effect of self-efficacy on behavioral intention to use AIS is 
significant. This result is consistent with previous findings which have found that selfefficacy is positively related to behavioral intention (Park, 2009). Self-efficacy is an intrinsic motivation factor that can help students in the learning process of AIS. According to social theory, Bandura's motivation, high selaf-efficacy will lead to a more active learning process.

Second, the direct effect of information quality on behavioral intention to use AIS is significant.To improve performance, students need quality information to make an academic decision. Information must have its value to the receiver to facilitate students in making effective decision making. Information quality will increase the intention of students to use AIS. The result is consistent with finding of earlier study (Liu et al., 2000).

Third, The indirect effect of self-efficacy and information quality on behavioral intention to use AIS through perceived usefulness is not significant. This study found that the external variables (self-efficacy and information quality) were found to be an essential determinant of perceived usefulness. This result provides support to the prior empirical findings mentioned above (Ahn et al., 2007; Chang et al., Lin, 2007; and Wang \& Lin, 2012).

A surprise finding of this study shows that perceived usefulness were not significant predictors in influencing the intention to use academic information system. This can be due to the majority of the students already knew the academic information system, and they feel that the system is convenient and made them satisfied with the system. As stated by a study done by Altawallbeh et al. (2015) that the unexpected factors or events can be a determinant to influence the intention to accept e-learning and attitude seems to be much more critical to the information system users.

The findings of this study add to the knowledge of information system research. There are remains a significant amount of research requiring to be done in this area to replicate or extend this study. In this study, the participants are from a single university future research can replicate using several universities, so that the results can be more generalized. Also, it is reasonable to expect that having a multi-group comparison between student and teachers could increase the applicability of the TAM in an Indonesian context. Finally, since technology will continue to grow and develop rapidly, a replication of this study should be conducted periodically to examine education technologies trends to update and provide appropriate knowledge and skills for students.

\section{REFERENCES}

Ahn, T., Ryu, S., \& Han, I. (2007). The impact of Web quality and playfulness on user acceptance of online retailing. Information \& Management, 44(3), 263-275.

Ajzen, I. (1988). Attitudes, personality, and behavior. Chicago: Dorsey Press.

Ajzen, I. (1991). The theory of planned behavior. Organizational Behavior \& Human Decision Processes, 50(2), 179-211.

Ajzen, I. (1996). The social psychology of decision making. In E.T. Higgins \& A.W. Kruglanski (Eds.), Social Psychology: Handbook of Basic Principles, 297-328.

Ajzen, I., \& Fishbein, M. (1980). Understanding attitudes and predicting social behaviour. Englewood Cliffs, NJ: Prentice Hall.

Altawallbeh, M., Soon, F., Thiam, W., \& Alshourah, S. (2015). Mediating role of attitude, subjective norm and perceived behavioural control in the relationships between their respective salient beliefs and behavioural intention to Adopt E- 
Learning among Instructors in Jordanian Universities. Journal of Education \& Practice, 6(11), 152-159.

Ariff, M. S. M., Yeow, S. M., Zakuan, N., Jusoh, A., \& Bahari, A. Z. (2012). The effects of computer self-efficacy and technology acceptance model on behavioral intention in internet banking systems. Procedia-Social \& Behavioral Sciences, 57, 448452.

Bandura, A. (1982). Self-efficacy mechanism in human agency. American Psychologist, $37(2), 122-147$.

Bandura, A. (1986). Social foundations of thought and action: A social cognitive theory (1 $\left.{ }^{\text {st }} \mathrm{ed}.\right)$. New York, N. Y.: Macmillan Publishing Company.

Bandura, A. (1997). Self efficacy: The exercise of control. New York: Freeman.

Bowen, W. (1986, May 26). The puny payoff from office computers. Fortune, 20-24.

Butt, I., Tabassam, S., Chaudhry, N. G., \& Nusair, K. (2016). Using technology acceptance model to study adoption of online shopping in an emerging economy. Journal of Internet Banking \& Commerce, 21(2), 1-18.

Compeau, D. R., \& Higgins, C. A. (1995). Computer self-efficacy: Development of a measure and initial test. MIS Quarterly, 19(2), 189-211.

Curley, K. F. (1984, July-August). Are there any real benefits from office automation? Business Horizons, 4, 37-42.

Davis, F. D. (1989). Perceived usefulness, perceived ease of use, and user acceptance ofinformation technology. MIS Quarterly, 13(3), 319-340.

Davis, F. D., Bagozzi, R. P., \& Warshaw, P. R. (1989). User acceptance of computer technology: A comparison of two theoretical models. Management Science, 35(8), 982-1003.

Eagly, A. H., \& Chaiken, S. (1993). The psychology of attitudes. San Diego: Harcourt Brace Jovanovic.

Eastin, M. S. (2002). Diffusion of e-commerce: An analysis of the adoption of four ecommerce activities. Telematics \& Informatics, 19(3), 251-267.

Edelman, F. (1981, September). Managers, computer systems, and productivity. MIS Quarterly, 5(3), 1-19.

Fishbein, M., \& Ajzen, I. (1975). Belief, attitude, intention, and behavior: an introduction to theory and research. Addison-Wesley: Reading, MA.

Forslund H., \& Jonsson, P. (2007). The impact of forecast information quality on supply chain performance. International Journal of Operations \& Production Management, 27(1), 90-107

Gist, M. E., \& Mitchell, T. R. (1992). Self-efficacy: A theoretical analysis of its determinants and malleability. The Academy of Management Review, 17(2), 183-211.

Guriting, P., \& Ndubisi, N. O. (2006). Borneo online banking: evaluating customer perceptions and behavioural intention. Management Research News, 29(1/2), 6-15.

Hsu, C. L., Lin, J. C. C., \& Chiang, H. S. (2013). The effects of blogger recommendations on customers' online shopping intentions. Internet Research, 23(1), 69-88.

Hu, Y., Sun, X., Zhang, J., Zhang, X., Luo, F., \& Huang, L. (2009). A university student behavioral intention model of online shopping. Paper presented at The International Conference on Information Management, Innovation Management \& Industrial Engineering (pp. 625-628), IEEE.

Jaturavith, W., Noormohamed, N. A., \& Massrour, B. (2007). Internet adoption by consumers in Thailand-competing in a globalized world. Competition Forum, 5(1), 156. 
Juniwati (2014). Influence of perceived usefulness, ease of use, risk on attitude and intention to shop online. European Journal of Business \& Management, 6(27), 218228.

Khairi, M. S., \& Baridwan, Z. (2015). An empirical on organizational acceptance accounting information system in sharia banking. The International Journal of Accounting \& Business Society, 23(1), 97-122.

Lai, E., \& Wang, Z. (2012, June). Empirical research on factors affecting customer purchasing behavior tendency during online shopping. Paper presented at IEEE International Conference on Computer Science and Automation Engineering (pp. 583-586), IEEE.

Li, C. (1997). ERP packages: What's next? Information System Management, 16(3), 31-35.

Li, S., \& Lin, B. (2006). Accessing information sharing and information quality in supply chain management. Decision. Support Systems, 42(3), 1641-1656.

Li, S., Ragu-Nathan B., Ragu-Nathan, T. S., \& Rao, S. S. (2006). The impact of supply chain management practices on competitive advantage and organizational performance. Omega, 34(2), 107- 124.

Lin, H. F. (2007). The role of online and offline features in sustaining virtual communities: An empirical study. Internet Research, 17(2), 119-138.

Lin, J. C. C., \& Lu, H. (2000). Towards an understanding of the behavioural intention to use a web site. International Journal of Information Management, 20(3), 197-208

Liu, C., Arnett, K. P., \& Litecky, C. (2000). Design quality of websites for electronic commerce: Fortune 1000 webmasters' evaluations. Electronic Markets, 10(2), 120129.

Lucas, H. C. (1975, April). Performance and the use of information System. Management Science, 21(8), 908-919.

Ma, W. W. K., Andersson, R., \& Streith, K. O. (2005). Examining user acceptance of computer technology: An empirical study of student teachers. Journal of Computer Assisted Learning, 21(6), 387-395.

Malhotra, Y., \& Galletta, D. F. (1999). Extending the technology acceptance model to account for social influence: Theoretical bases and empirical validation. The 32nd Annual Hawaii International Conference on System Sciences (pp. 1-14), IEEE.

Mathieson, K. (1991). Predicting user intentions: Comparing the technology acceptance model with the theory of planned behaviour. Information Systems Research, 2(3), 173-191.

Mathieson, K., Peacock, E., \& Chin, W. W. (2001). Extending the technology acceptance model: The influence of perceived user resources. Database for Advances in Information Systems, 32(3), 86-112.

McKinney, V., Yoon, K., \& Zahedi, F. M. (2002). The measurement of web-customer satisfaction: An expectation and disconfirmation approach. Information Systems Research, 13(3), 296-315.

Miller, H. (2005). Information quality and market share in electronic commerce. Journal of Services Marketing, 19(2), 93-102.

Moberg, C. R., Cutler, B. D., Gross, A., \& Speh, T. W. (2002). Identifying antecedents of information exchange within supply chains. International Journal of Physical Distribution \& Logistics, 32(9), 755-770.

Monczka, R. M., Petersen, K. J., Handfield, R. B., \& Ragatz, G. L. (1998). Success factors in strategic supplier alliances: The buying company perspective. Decision Sciences, 29(3), 553-577. 
Moon, J. W., \& Kim, Y. G. (2001). Extending the TAM for a World-Wide-Web context. Information \& Management, 38(4), 217-230.

Moore, G. C., \& Benbasat, I. (1991). Development of an instrument to measure the perceptions of adopting an information technology innovation. Information Systems Research, 2(3), 192-222.

O'cass, A., \& Fenech, T. (2003). Web retailing adoption: Exploring the nature of internet users web retailing behaviour. Journal of Retailing \& Consumer Services, 10(2), 81-94.

Omar, R., Ramayah, T., Lo, M. C., Sang, T. Y., \& Siron, R. (2010). Information sharing, information quality and usage of information technology (IT) tools in Malaysian organizations. African Journal of Business Management, 4(12), 2486-2499.

Park, S. Y. (2009). An analysis of the technology acceptance model in understanding university students' behavioral intention to use e-learning. Educational Technology \& Society, 12(3), 150-162.

Rabren, J. (2010). Technology, integration and data drive supply chain visibility. Material handling management. Retrieved Business Source Complete database, 65(3), 42.

Raghunathan, S. (1999). Impact of information quality and decision-maker quality on decision quality: A theoretical model and simulation analysis. Decision Support Systems, 26(4), 275-286.

Ramayah, T., \& Ignatius, J. (2005). Impact of perceived usefulness, perceived ease of use and perceived enjoyment on intention to shop online. ICFAI Journal of Systems Management (IJSM), 3(3), 36-51.

Roca, J. C., \& Gagné, M. (2008). Understanding e-learning continuance intention in the workplace: A self-determination theory perspective. Computers in Human Bebavior, 24(4), 1585-1604.

Sari, A., Akkaya, M., \& Abdalla, B. (2017, February). Assessing e-government systems success in Jordan (e-JC): A validation of TAM and IS success model validation of TAM and IS for e-government systems success in Jordan. International Journal of Computer Science \& Information Security, 15(2), 277-304.

Sharda, R., Bar, S. H., \& McDonnell, J. C. (1988). Decision support system effectiveness: An review and empirical test. Management Science, 34(2), 139-159.

Swanson, E. B. (1974). Management information systems: Appreciation and involvement. Management Science, 21(2), 178-188.

Swanson, E. B. (1987). Information channel disposition and use. Decision Sciences, 18(1), 131-145.

Teo, T. S. H., Srivastava, S. C., \& Jiang, L. (2008). Trust and electronic government success: An empirical study. Journal of Management Information System, 25(3), 99-131.

Urbach, N., Smolnik, S., \& Riempp, G. (2010). An empirical investigation of employee portal success. The Journal of Strategic Information Systems, 19(3), 184-206.

Van der Heijden, H. (2003). Factors influencing the usage of websites: The case of a generic portal in The Netherlands. Information \& management, 40(6), 541-549.

Wang, K., \& Lin, C. L. (2012). The adoption of mobile value-added services: Investigating the influence of IS quality and perceived playfulness. Managing Service Quality, 22(2), 184-208.

Wang, Y. S., \& Liao, Y. W. (2008). Assessing e-government systems success: A validation of the DeLone and McLean model of information systems success. Government Information Quarterly, 25(4), 717-733. 
Wirtz, J., \& Chew, P. (2002). The effects of incentives, deal proneness, satisfaction and tie strength on word-of-mouth behaviour. International Journal of Service Industry Management, 13(2), 141-162.

Yi, M. Y., \& Hwang, Y. (2003). Predicting the use of web-based information systems: Self-efficacy, enjoyment, learning goal orientation, and the technology acceptance model. International Journal of Human-Computer Studies, 59(4), 431-449.

Young, T. R. (1984, April 1). The lonely micro. Datamation, 30(4), 100-114. 